Island Studies Journal, Vol. 6, No. 2, 2011, pp. 179-202

\title{
Autonomy Initiatives and Quintessential Englishness on the Isle of Wight
}

\author{
Adam Grydehøj \\ Island Dynamics \\ and \\ The Elphinstone Institute \\ University of Aberdeen, Scotland \\ agrydehoj@islanddynamics.org
}

and

Philip Hayward

Southern Cross University

Lismore, Australia

phayward2010@gmail.com

\begin{abstract}
This article addresses the nature of autonomist impulses and initiatives that developed on the Isle of Wight, off the southern coast of England, in the late $20^{\text {th }}$ Century. Drawing on recent discussions of the process of decolonization of island territories and the broader field of study of ethnopolitical mobilization in support of regional autonomy, the article considers the reasons why local autonomist initiatives failed to secure significant traction with the local population. Focus is placed on the historical process of identity building, on how the Isle of Wight community conceptualizes its relationship with England as a whole and of the manner in which the island and its heritage has been considered as quintessentially English.
\end{abstract}

Keywords: autonomy; Englishness; islands; Isle of Wight; local identity; nationalism; politics; tourism

(C) 2011 Institute of Island Studies, University of Prince Edward Island, Canada

\section{Introduction}

The United Kingdom of Great Britain and Northern Ireland (UK) is a constitutional entity that has accreted over an extended historical period. Alongside its four component countries (England, Scotland, Wales, and Northern Ireland), it includes three crown dependencies located on islands (the Isle of Man and the bailiwicks of Guernsey and Jersey). Formally, these three island territories are neither part of the UK nor of the European Union (EU) (the precursor of which - the European Community - the UK joined in 1973). As a result, the crown dependencies have managed to establish lucrative financial industries outside of UK tax legislation, exercise significant autonomy over local matters, and exploit their cultural differences and island locales as tourist attractions. 
The crown dependencies' success in these respects has attracted the interest of members of other island communities who aspire to greater autonomy within the UK. Orkney and Shetland provide the most prominent examples, supporting separate autonomist movements that contested the national parliamentary constituency in the 1987 national elections with a joint candidate (who secured $15 \%$ of the vote) although the initiative fragmented over the following decade. Despite changes in national county boundaries (most notably in 1972, as a result of "The Local Government Act") and in the increased autonomy of Wales and Scotland over the last three decades, no British island has succeeded in gaining significantly enhanced de jure autonomy over the last century.

This article profiles the Isle of Wight (henceforth IOW), an area in which locally focused initiatives have been mounted but have failed to establish themselves due to a lack of support from the local population. We analyze the impetus behind these movements and their relationship with broader aspects of island identity as well as the advantages and disadvantages of autonomy. Our analysis thereby examines a number of contentions advanced by Baldacchino (2004) in his survey of the theorization of island societies. In particular, its findings support Baldacchino's argument that the state of islandness per se does not necessarily create the community basis for a unified island identity that is oppositional to the "economic and cultural hinterland" of adjacent mainlands or other islands (Streeten, 1993). Similarly, we explore the processes that have created a sense of space and community in the island locality. We also consider the "vaulting ambition, which overleaps itself" (Shakespeare, 1605: 1.7.16) of political pressure groups whose vision for the IOW is significantly discordant with the community perceptions discussed below. In these regards, our analysis converges with research undertaken on ethnopolitical mobilization and, in particular, on predictive modelling and identifications of thresholds for successful autonomy, such as Cartrite (2004), by assessing which "necessary conditions for ethnopolitical mobilization" (Cartrite, 2010: 242) were not present on the IOW in the period in question.

\section{Location and History}

The IOW is located off the south coast of England and is separated from the adjacent county of Hampshire by the Solent Channel, which ranges from 5-8 kilometres in width. The principal links to the mainland are ferry and hovercraft services from the mainland ports of Southampton, Portsmouth, and Yarmouth. The island has a population of approximately 140,000 and a landmass of $385 \mathrm{~km}^{2}$. Administratively, the IOW is one of England's 83 constituent counties and is administered by a single local council authority. The IOW is currently the largest UK parliamentary constituency in terms of population but is set to split into two constituencies as part of UK-wide reforms aimed at equalizing constituency sizes.

Like many other areas of the contemporary UK, the IOW experienced both substantial autonomy and shifting alliances with regional powers prior to the arrival of the Romans around 43 AD. During its 450-year period of Roman occupation, the IOW was commonly referred to as Vectis. After the withdrawal of the Romans, the island fell under the control of a group of Jutish colonists from Northern Germany and was effectively an independent territory until 685 $\mathrm{AD}$, when it was forcibly acquired by the Kingdom of Wessex. Following the Norman Conquest in 1066, the island was granted to the De Redver family whose position as hereditary 
lords allowed them considerable autonomy. This situation was dissolved when King Edward I claimed that the island's hereditary ruler, Isabella de Fortibus, had sold him the island on her deathbed, and he assumed the island as Crown property in 1293. Although the island has been administered as part of England ever since, one persistent legacy of its previous autonomy was the appointment of a ceremonial Governor, a practice that only ceased in 1995.

Despite the island's medieval autonomy, its close proximity to the mainland and the sheltered passage afforded by its alignment roughly parallel to the southern English coast have ensured a substantial degree of interaction with the county of Hampshire to the north. While local traditional practices and a distinct IOW dialect have been identified by amateur historians and folklorists (see particularly Long, 1886), these are regional variants and inflections of southern English - and specifically Hampshire - traditions.

\section{Figure 1: Family seaside tourism in Shanklin, Isle of Wight.}

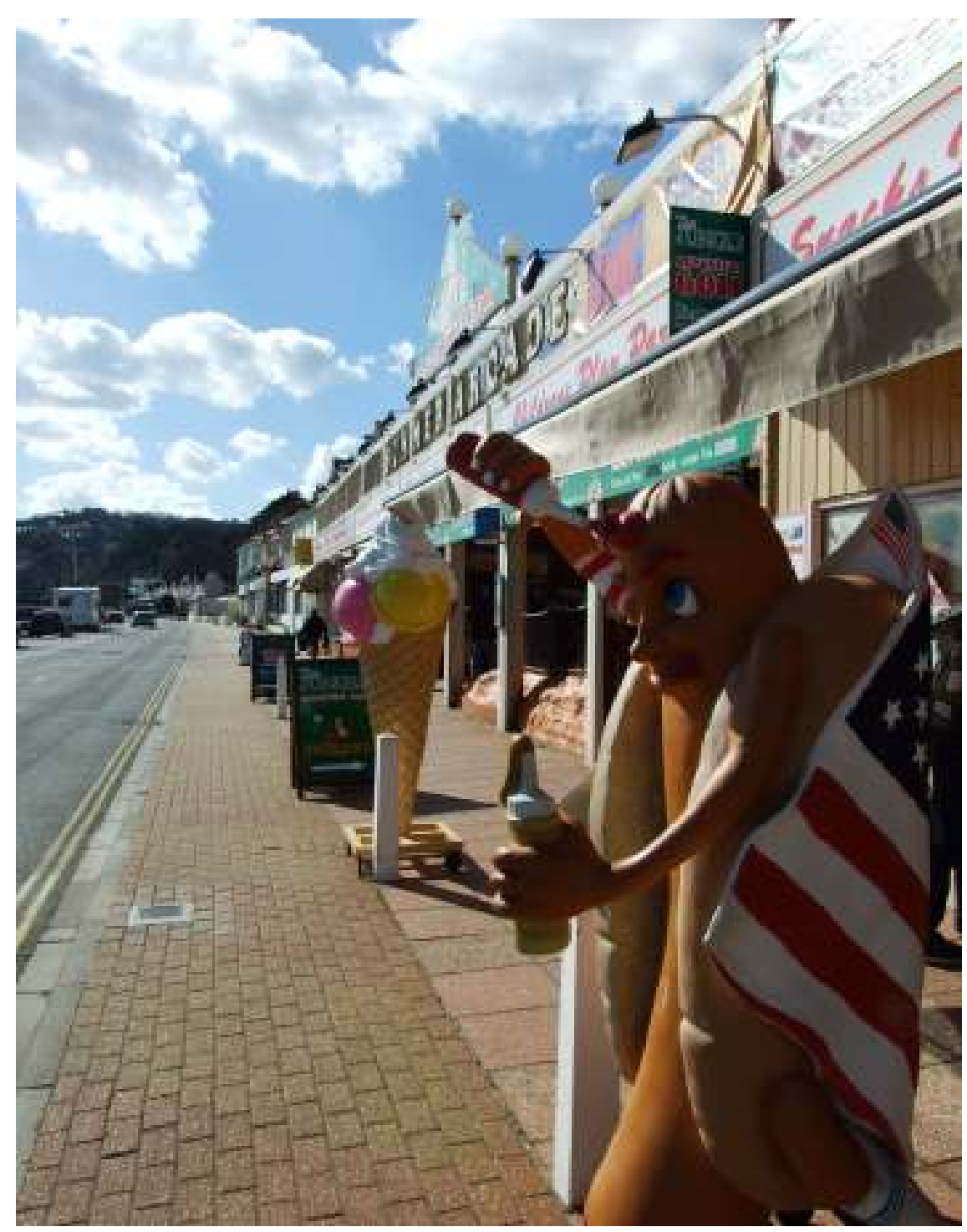

Photo by Adam Grydehøj 
Royal patronage ranks among the reasons why, during the 1800 s, the IOW became increasingly linked with not only the mainland but also specifically urban mainland society. King George IV began a period of royal endorsement of the island through his official patronage of the Royal Yacht Club (later renamed Royal Yacht Squadron), which established an annual sailing regatta at the port of Cowes in 1826. Held in August, the event became firmly established on the British aristocracy's social calendar and attracted visitors for both its sailing schedule and onshore festivities, such as its closing fireworks displays. Queen Victoria continued the royal endorsement by having Osbourne House constructed near Cowes in the late 1840s. She was a frequent summer visitor and eventually died there in 1901.

Due in part to the Queen's patronage, the IOW became an increasingly fashionable tourism location in the mid-1800s, which in turn vastly improved transport links with the mainland. In 1840, the seaside town of Ryde constructed a pier to service visitors arriving on ferries from Portsmouth. Further piers followed in 1864 and 1880, upon which entertainment facilities were installed. The 1880 pier, known as 'Seaview', was one of England's longest (around 300 metres) and was a tourist attraction in its own right. Tourist transportation around the island was enhanced by the establishment of two railway companies in the 1860 s, connecting the island's ports and towns, with further branch lines opening in the 1880s.

In the late 1800 s and early 1900 s, the island's socio-economic links across the Solent were strengthened by increased traffic between the island and mainland, by associated infrastructural developments, and by increased reliance on income from mainland tourists. The post-WW2 period saw a steady population growth, with an annual increase of around 6\% occurring between 1981 and 1991, resulting in the current all-time high population of around 140,000 . Much of this rise is due to the migration of aged and/or retired individuals from the mainland, with this demographic constituting $25.3 \%$ of the 2005 population, compared to the English and Welsh national average of 18.5\% (IOW Council, 2005: 35) Recent decades have also witnessed substantial numbers of young people (i.e., 15-29 year olds) relocating to the mainland for work and education. Another significant demographic concerns the island's ethnic make-up, 2009 Statistics compiled by the Office for National Statistics and published in May 2011 reveal the following details (see Table 1).

Table 1: Relative distribution of 'white British' residents versus others

\begin{tabular}{|lcc|}
\hline & White British & Various Other \\
\hline & & \\
\hline Mean for England and Wales & $84.0 \%$ & $16.0 \%$ \\
\hline Mean for London & $59.5 \%$ & $40.5 \%$ \\
\hline Mean for IOW & $95.1 \%$ & $4.9 \%$ \\
\hline
\end{tabular}


As the above account suggests, the situation of the IOW from the early $19^{\text {th }}$ to early $2^{\text {st }}$ Century has been one of increasing incorporation into a mainland southern English socialcultural space with which it had close economic association. In this regard, the IOW's historical trajectory was distinctly different to the "fairly common "story" of ethnopolitical mobilization toward autonomy in Western Europe in the post-War era, which Cartrite has characterized in terms of:

- "Romantic intellectual nationalism generating an interest in a local identity (particularly language preservation)";

- "subsequent political activism" around the local identity "imagined" (Anderson, 1983) by activists;

- political organizations emerging to raise "more specific demands for institutional accommodation" of autonomist sentiment; and, finally

- "a bid for self-determination" (Cartrite, 2010: 240-241).

In light of the history, shifting demography, and lack of distinct IOW identity outlined above, the first modern separatist impulses that manifested themselves on the IOW in 1960s are best understood as opportunistic attempts to engage with wider geopolitical contexts and temporalities in order to gain local advantages and protections rather than as 'organic', 'grassroots' responses to socio-political change.

\section{The 1960s - Early 1970s}

Following the establishment of the United Nations (UN) in 1945, with Chapter 11 of its charter identifying decolonization as a goal, the post-WW2 period saw a wave of successful campaigns of independence for former colonial territories. Further impetus for such projects was provided by the UN's Declaration on "Granting of Independence to Colonial Countries and Peoples" in 1960, with its Resolution 1541 identifying "three legitimate options of full self-government" as "free association with an independent State, integration into an independent State, or independence" (UN, 1960). As one of the world's major colonial powers, the UK was particularly affected by the phenomenon as a series of its former imperial territories were reconstituted as independent countries within the British Commonwealth, including India and Pakistan (1947), Malaysia (1957), Jamaica (1962), and Trinidad and Tobago (1962). One territory that attracted major attention internationally and became a significant problem for its former imperial power was Southern Rhodesia. This colony's white minority government, under the leadership of Prime Minister Ian Smith, issued a Unilateral Declaration of Independence (UDI) in 1965 in opposition to British policy not to grant independence until majority rule had been established. With Britain imposing sanctions against its former colony at a time of growing anti-immigration sentiment and overt racism in the UK (such as that promulgated by the politician Enoch Powell), the isolation of Rhodesia's white minority attracted considerable sympathy in Britain and was prominently featured in British media. 
One local reflection on Rhodesia's UDI is significant, even as satire, for presaging more serious local consideration of "options of full self-government" (UN, 1960) for the IOW. In 1967, Lauri Say, an amateur performer (originally from London), wrote and began performing a song entitled "UDI for IOW". This song was included on a four-track vinyl EP entitled "Songs for Singing Islanders", which was released in 1968 and also included the tracks "The IOW for Me", "The Southern Vectis Bus Song", and "The Hovercraft". The opening verse and chorus of "UDI for IOW" state the song's main thesis:

Down in sunny Africa, things are getting tough

Because of the behaviour of a man called Ian Smith

Now, you may think he's a traitor

Or you may think that he's right

But we could follow his example on the Isle of Wight!

High the Island, Ho the Island, High the Isle of Wight!

High the Island, Ho the Island, High the Isle of Wight!

Oh, we'll pick up our pitchforks and give them such a fight

And declare independence on the Isle of Wight.

Contrasting this rebellious scenario to cold realities, the song's concluding verse suggests the economic folly of such an enterprise:

We'll have mounds and mounds of seaside rock

And nobody to buy 'em

They won't need to send the troops in

They'll just sit and bide their time

And when our economy at last begins to crack

Then we'll ask the British Government to take us back!

Another topical reference within the song refers to a different example of British offshore autonomy, "We'll jam the $\mathrm{BBC}$ if they try to intervene/And set up a pirate radio on the Medway Queen." The Medway Queen was a paddle steamer moored in Island Harbour and used as a clubhouse and nightclub in the 1960s. This reference to "pirate" radio broadcasting refers to the establishment of a number of unlicensed and unauthorized commercial radio stations (broadcasting primarily pop music) during the mid-1960s. Broadcasts took place from either ships moored in international waters, outside the (then) three-mile territorial limit (following the example of Radio Caroline, established in 1964) or from fixed platforms, such as Radio Essex (established in 1965), which operated from Fort Roughs, an abandoned military structure on the Rough Sands sandbar off the Suffolk coast. Fort Roughs has since attracted attention following its occupier's declaration of the fort as a "micronation" called the Principality of Sealand (Dennis, 2002). These offshore media enterprises - and, as pertinently, the British Government's attempts to shut them down by various means (see Johns, 2010) attracted public attention to the limits of British authority over its offshore waters. 
Against this backdrop of national and international negotiations of British rule and local selfdetermination, a group of island residents founded the Vectis National Party (VNP) in 1967 to explore the possibility of increased autonomy within the UK. Unproductive searches in IOW archives and the UK's National Archives, as well as the lack of reference in contemporary media accounts, lead us to believe that no formal VNP manifesto was ever published. VNP activists, however, asserted the need for more local autonomy premised on a particular notion of an essential (pre-modern) "IOWness" (discussed further below) under threat from various agents and effects of modernity (also see the second stage VNP manifesto discussed in section III below). The party's autonomist slant led it to briefly undertake symbolic direct action, such as an intra-island postal service during the 1971 postal strike (Brasher, 2011). Despite a shortlived surge of activity on the part of a small group of enthusiasts, the lack of a clear and coherent agenda appears to have inhibited the party's progress, and when R.W.J. Cawdell stood as a VNP candidate in the 1970 Parliamentary elections he secured only 1607 votes (2.8\% of the constituency total) (Tetteh, 2008: 37). The Party's energy and profile dissipated soon after.

\section{Regional Development}

Over the following decades, as international political cooperation in Europe became entrenched, new expectations formed for island communities. The EU's focus on addressing disparities of living standards and infrastructure in regional locations is expressed in its Priority Objective \#1, "to promote the development and structural adjustment of regions whose development is lagging behind" (European Commission, 1999). This has attracted regional pressure groups, some of which had long expressed autonomist/separatist sentiments that included assertions of underdevelopment. Following consultation and lobbying in the late 1990s, Cornwall, Wales, the Isles of Scilly, and the Highlands \& Islands of Scotland successfully argued their eligibility for access to a funding pool equivalent to $35 \%$ of the EU's overall regional assistance budget (a proportion amounting to 213 billion euro in 2000-2006) (European Commission, 1999).

One local attempt to emulate the success of these more sustained regional initiatives occurred in the form of the Isle of Wight Party (IWP). Phil Murray, the IWP's founder, argued for a dynamic new IOW empowered by the economic networks and the benefits of the European Community. The IWP's manifesto opens with the explanation that:

The Isle Of Wight Party, has been founded specifically to represent Isle Of Wight residents at a local, national and international level, aware of special Island needs, and in harmony with The United Kingdom and The European Union. (IWP, 2001)

The emphasis on "special Island needs" here is significant in that there is no attempt to claim any cultural difference for the IOW from the UK but rather an attempt to identify islandness as the chief issue. The manifesto then goes on to identify its key policy as the establishment of a "fixed link", i.e., a bridge between the island and mainland. The IWP asserts - against, as we shall see, the dominant tide of public opinion - that such a project need not have negative outcomes, claiming that: 
Those residents who feel that our roads cannot cope with any extra traffic, or any increase in visitors, must also realize that their personal economies are intrinsically a part of this very capability ... the island['s] capacity to successfully entertain visitors. Currently, we all depend on tourism either directly or indirectly. It is the mainstay of the Isle Of Wight's economy. In time we can spread our Island economy across a broader spectrum of interests (IWP, 2001).

The manifesto claims that, when such a link is established, "a very prosperous and ecologically friendly future, will dawn sooner, rather than later, for Island residents" (IWP, 2001). Together with proposals to establish a university on the island and to upgrade other facilities, the manifesto recognises the decline in local tourism (see Hjalager, 1998), affected by factors such as an increase in cheap travel to European destinations. Reflecting this, the IWP prioritized a broadening and rebranding of local tourism, with a focus on "organic and free range" agricultural produce (IWP, 2001).

With Phil Murray as candidate, the IWP contested the 2001 general elections, gaining 1164 votes (1.83\% of the constituency vote), a figure that suggests little widespread approval for a fixed link to the island or for Phil Murray's role as an incomer political activist.

In 2006, Ray Stokes attempted to revive the VNP, identifying the new VNP as setting out "to debate and gauge the depth of feeling regarding some form of devolved government similar to that of the Channel Islands or the Isle of Man." Interestingly, the new VNP possessed quite a different expressive character from the IWP, emphasizing two aspects: an economically opportunistic deployment of islandness alongside a conservative and nostalgic impulse. The VNP's "Assessment" of the IOW's political situation asserts the necessity for local control premised on a particular imagination of the island's essential characteristics from a particular age and class position. It also comes out against plans for substantial development of new housing. The document characterizes the IOW as "largely un-spoilt, rural ... and littered with quaint little villages of thatched cottages." This ignores the considerable infrastructure associated with the tourist industry and the growth of the island's towns and downplays the presence of light and heavy industry. The assessment goes on to identify the "slower pace of life than the mainland" as "one of the island's biggest assets" since "the majority of visitors to the islands are middle aged and above and can enjoy the peace and quiet life which is virtually extinct on mainland England" (VNP, 2006). The definition of local character being advanced here is produced through the intertwining of nostalgia and tourist promotion.

In addition to identifying housing development as encouraging further problematic migration from the mainland, the VNP's 2006 statement also raises the spectre of disruption caused by the imposition of a fixed link between the island and mainland Britain (also Baldacchino, 2007). In contrast to the IWP, which saw a fixed link as beneficial, the revived VNP warns of major demographic changes that would "inevitably" follow:

A new bridge will spell the death knell for the Isle of Wight which will bring an overspill area for the South of England making way for an increase in urban housing on a scale that will quickly destroy the culture and character of the island forever (VNP, 2006). 
Despite there being no clear plans for such a bridge at any recent time, the VNP uses the threat of a bridge as the most compelling reason for the IOW's devolution, arguing that devolution would permit local rejection of any bridge proposals. The VNP's manifesto also expresses hope that devolution would replace established British party politics with a system in which local politicians could "develop a sense of belonging and a pride in their island" as in the Isle of Man, which the VNP regards as a paragon of productive political cooperation (VNP, 2006).

Whereas Phil Murray's IWP was not precisely autonomist, the revived VNP's aims for devolution are wide ranging, ambitious, and unlikely, including leaving the EU and adopting "a tax haven status." In addition, the VNP suggests imposing restrictions, monitoring the population, and limiting housing in order "to protect the island rural culture and way of life":

Housing can be restricted by proof of residency prior to independence, all new comers will have to provide proof of sustained employment on the island, or provide either wealth or new industry to the island economy ... The island will have the opportunity to gear itself to the primary source of economy, tourism. Autonomy will allow and foster the island's unique culture. Under Autonomy it will be possible to have our own currency, stamps and car registrations (VNP, 2006).

Unlike the IWP or the first VNP, the revived VNP failed to contest any election.

What accounts for the failure of these attempts to mobilize specific island-wide political initiatives aimed at either the preservation of an imagined idyllic IOW or at the island's dynamic development? Ethnographic research undertaken by the authors in 2010 offers some possible answers and indicates a precarious balance between the two impulses.

Figure 2: A constructed rural idyll in heritage tourism: the Old Smithy, Godshill, Isle of Wight.

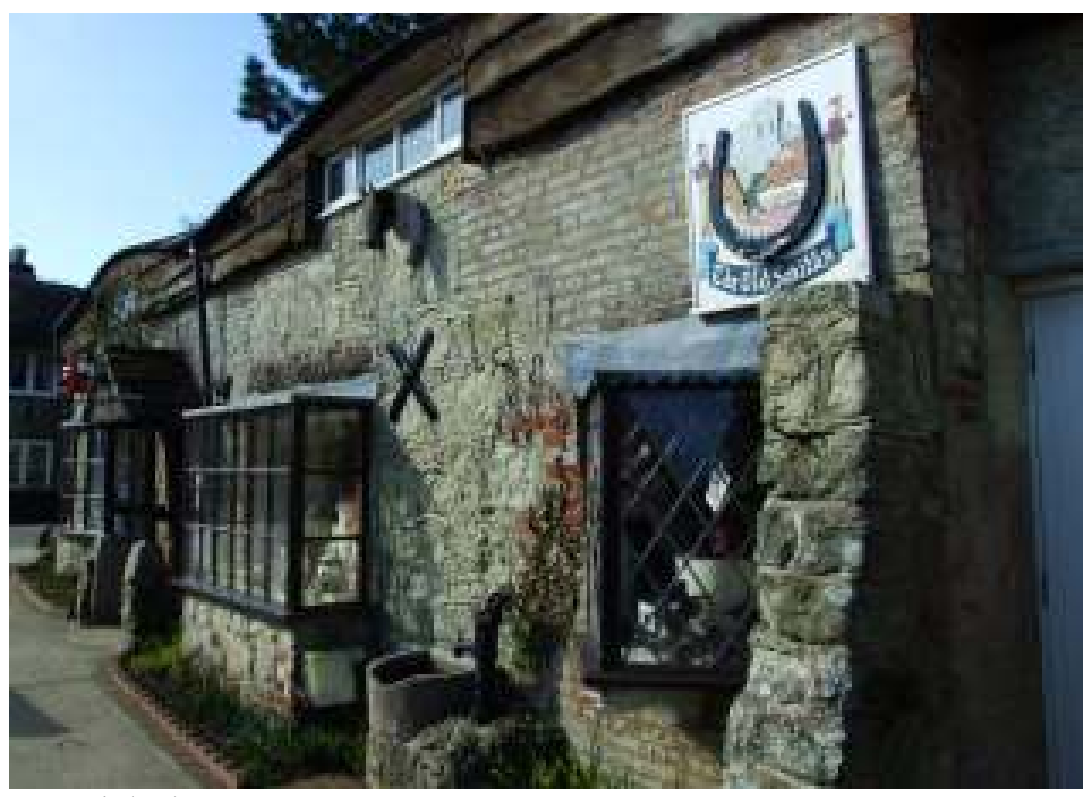

Photo by Adam Grydehøj 


\section{A. Grydehøj \& P. Hayward}

\section{Methodology and Ethnography}

Adam Grydehøj undertook ethnographic fieldwork on the IOW in March 2010. This fieldwork consisted of participant observation, casual conversation, informal interviews, and semistructured formal interviews performed in person among individuals, couples, and small groups. Formal recorded interviews took place with 15 individuals, some of whom were interviewed on more than one occasion. Contributors were selected through a combination of the network method - designed to elicit the opinions of "regular" IOW residents - along with targeted selection of individuals whose work suggested that they would have given particular thought to or would have particular knowledge of the IOW's historical and political development.

Formal interviews averaged between 45 minutes and two hours in length. Interviews covered a variety of issues in order to identify links between disparate elements of the local identity. All formal contributors discussed: what (if anything) makes the IOW unique; how residents conceive of, and relate to, the island's history; how the IOW's island status affects its relationship with neighbouring jurisdictions, other British islands, and the UK as a whole; how incomers and the tourism industry affect the island; and, lastly, what jurisdictional form would be most suitable for the island.

We have chosen to name our contributors when quoted, provided that they have given their permission for us to do so and provided that we feel that such attributed quotations will not harm the contributor. All formal interview contributors, whether anonymous or otherwise, signed release forms that assign to them ultimate ownership over their contributions to audio recordings and provide various opt-in levels of consent for use of these materials by the authors and by the Elphinstone Institute of the University of Aberdeen. Although other disciplines have different traditions of contributor ownership and naming, we follow common practice in the discipline of folklore, asserting the right of contributors to have control over their own words.

The relatively small number of formal interviews is the dual result of limited time in the field and a marked reticence to be recorded among many contributors. All but one of the individuals who Grydehøj contacted in advance and/or contacted with prior introduction agreed to be interviewed and recorded; this was not the case when Grydehøj attempted to interview individuals without advance contact and/or prior introduction. In such cases, individuals were largely happy to speak about their views concerning the IOW but were generally unwilling to make use of the interviewer's pocket audio recorder. Although even self-employed contributors tended to regard the audio recorder with suspicion, this feeling was especially prevalent among public sector employees, who seemed anxious about angering their employers. Indeed, with a few exceptions, the Isle of Wight Council proved singularly unhelpful in facilitating this research, most notably by insisting that all contact take place via the council's Media \& Communications office. Such a policy may aim to impose public relations uniformity, but local authorities like the IOW Council should be aware of the drawbacks to such an approach: The result is simply that researchers are left with a lack of informed official opinions and a poor impression of the local government's lack openness and trust in its employees. 
As a result of these obstacles, most interviews were highly informal, conducted without even the aid of note taking. A total of around 30 individuals took part in such informal interviews, with participant observation and casual conversation bringing Grydehøj into contact with a far greater number of residents and visitors (and further information being gained from email correspondence with additional individuals). Contributors as a whole were spread across the island's age, class, geographical, and gender groups, but the digitally recorded, semi-structured interviews were limited to adults, both incomers and IOW natives.

Due to their relative unsuitability for quantitative analysis, the combined data from observation, casual conversation, formal and informal interviews, and e-mail correspondence is understood as subjective. Where expressions such as "most IOW residents feel ..." are used, it is with the awareness that absolute certainty regarding these statements would be impossible to achieve in practice. Such generalizations should be taken as referring to the prevalence of opinion and not as claims for a monolithic IOW identity.

Among the weaknesses of ethnographic fieldwork data are a lack of repeatability due to individualized questioning and small sample sizes due to the time-consuming nature of this method. Despite these drawbacks, ethnography presents a number of benefits, which give it a valuable place alongside more quantitative techniques as well as alongside other kinds of qualitative techniques, such as surveys, questionnaires, and focus groups. One important advantage is that individualized interviews allow a skilled researcher to question contributors in a language with which they are comfortable and to elicit answers without prompting, which prevents the contributor from giving particular answers solely to fulfil the perceived desire of the researcher. The ability to adapt questions over time also allows the researcher to cumulatively test previously collected data.

In addition, because research questions occur as part of a more-or-less natural conversation, the researcher is able to explore issues brought up by the contributor that may not have been known to the researcher in advance. In the present case, for example, the authors of this paper possessed a number of incorrect prior assumptions about IOW identity. Had a different type of qualitative method been pursued, the data may have been more numerically significant, yet lack of individualization and adaptability in questioning could conceivably have resulted in the authors never discovering that their assumptions were incorrect. We can see this process in action in the IOW Council-produced Isle of Wight Residents' Survey (Odedra, 2010), which has impressive numerical scope but is able to provide answers only to the questions that the survey asked and thus cannot offer a nuanced analysis of the issues at hand and is of limited relevance and usefulness to this study. 


\section{Autonomy}

No individuals encountered in the fieldwork expressed any desire - whether concrete or abstract - for increased IOW autonomy. Indeed, merely asking the question took considerable explaining since the concept was foreign to most contributors. This in itself points to the minimal effectiveness of the VNP in putting such policies on the community agenda. Devolution of significant powers to the IOW Council or another body is not seen as one jurisdictional option among many; it simply does not factor into the equation at all.

Jill Downer (57 years old), a life-long resident of the village of Shorwell, feels that talk of greater autonomy would simply be begging the question as to why anyone would want more local powers to begin with:

There's been nothing to sort of make you think like that. We've been treated all right ... We are part of, you know, the rest of England.

Similarly, William (pseudonym) (49), who grew up in the West Midlands of England and has been living on the IOW for over a decade, argues that considerable devolution of power has already occurred with the jurisdictional separation of the IOW from Hampshire. In discussing why the island would not benefit from increased powers, William thinks in economic terms, contrasting the IOW's situation with those of the British crown dependencies:

That stretch of water isn't long enough. It's weird ... I think it's three miles, and then you get the VAT exempt and things like that. So, you've got places like Jersey and the Isle of Man. You've got people with a lot of money who can come in, and then they ... have got their own governments within things. But we're that close we're not like a tax haven or anything like that.

This argument is circular: the Channel Islands and the Isle of Man possess special tax regimes as a result of their historically derived exceptional jurisdictional capacities, not the other way around. Legally speaking, distance from the mainland is irrelevant.

Alan Phillips (62) moved to the island in the 1960s. He first lived in Bembridge but is now a long-time resident of Shorwell. Phillips helped set up many of our interviews on the island and is an active member of the Island Storytellers and other local cultural groups as well as an extremely knowledgeable local historian. He is alone among our contributors in actually recalling the existence of the VNP in either of its manifestations. It should be noted that most contributors do not even recall the relatively recent IWP. Alan Phillips explains the lack of desire for more autonomy as the result of "such disillusionment generally with politicians of all sorts," including the island's current administration.

Nevertheless, although distrust of politicians may be a reason for not voting for autonomist parties, it does not seem to have obstructed autonomist sentiment in other island communities. For instance, the lack of success of autonomist political movements in Orkney and Shetland, where politicians - like, perhaps, politicians the world over - are viewed as ineffective, bears little relationship to the continued strength of autonomist sentiment (Grydehøj, 2010, 2011). 
Indeed, individual Shetland Movement candidates were fairly successful in the 1986, 1990, and 1994 local government elections, and Sandy Cluness (a Shetland Movement candidate in 1986) has served as Shetland Islands Council Convener since 2003. Support for a nationalist narrative and willingness to elect autonomy-minded politicians to local government does not always imply a desire to seek actual changes in jurisdiction. Nationalism might be essential to most kinds of devolutionist, secessionist, or autonomist sentiments, yet these sentiments are not necessary corollaries of nationalism. In the present context, we use the term "nationalism" to denote the perception that a particular group of people represents a distinctive ethnic group or nation, regardless of issues of statehood or territoriality.

\section{Uniqueness}

The willingness of individuals like William, Phillips, and Downer to discuss the potential for greater autonomy in terms of economics and other essentially practical motivations (dislike for particular local or national government policies) highlights the absence of true nationalist sentiment on the IOW. Although the seeking of comparative advantage may strengthen preexisting nationalist resolve (Bartmann, 2000: 43-44), there is little evidence for autonomist movements thriving on the basis of potential comparative advantage alone. The lack of nationalist sentiment on the IOW does not fundamentally concern a failure of political imagination or a level-headed evaluation of the economic merits and detractions of greater local power; instead, it concerns a lack of island-wide identity. The lack of a distinctive concept of IOW identity is clear even in the IOW Council's "Island Plan" (2005), which expansively identifies the IOW as having "a diverse culture and unique identity contributed to by people who are islanders by birth, newcomers to the island and visitors to the island" (IOW Council, 2005: 34) - a statement of such breadth that it is virtually meaningless.

When asked what makes the IOW special or unique, most residents - natives and incomers alike - respond by stating that it is an island. For instance, Jill Downer's response is:

It's not like you can roll up the motorway and get yourself into another city. You can't do that. And it's quite an expensive thing to get to the island, which, um, in some regards I believe is a sort of protection ... I think it keeps out the loutish elements. Because it just prices them out of being able to come over here. So, that's why I think the water is our protection. I do. And it is a slower pace of life here.

Jill Downer and her husband Barry Downer (63) are concerned that the building of a bridge to the mainland would attract undesirable individuals to the island. This is a common sentiment on the IOW as well as in other island communities (Baldacchino, 2007), though our contributors do not generally seem to have considered why undesirable individuals would want to visit or move to the IOW to begin with. For instance, one man in his 40s with whom I discussed the issue is worried that a bridge would make the island unsafe for children since paedophiles would then be able to drive onto and off of the island unnoticed. There is, indeed, a broader implied feeling within the community that the island holds a special attraction for criminals. This points to a rather undefined and unarticulated sense of IOW exceptionalism. Residents cannot say what makes the island better than other places; they are just convinced that it is better and that people who do not live on the island know that it is better. 
The new VNP embraced the idea that the IOW features a slow pace of life. This idea is mentioned not only by Jill Downer but by most of our other contributors as well. For example, Alan Phillips and his wife Renella Phillips (56), who is an IOW native, regard this as a function of insularity and as one of the IOW's defining features. When asked what makes the island unique, they respond:

Renella Phillips: It's very difficult to answer without coming up with something that just sounds clichéd, like, "Oh, the countryside's lovely, and you know, the climate's a bit warmer than it is in the rest of England," and all that sort of thing. Which is absolutely true, but you know, it is very difficult to think of something, something that doesn't sound like a tourist brochure ... I don't know if it still is a little bit quieter than mainland England. Less so than it was.

Alan Phillips: Less so than it was.

Renella Phillips: Less so than it was, but it's still ... a bit less frenetic, I think.

Alan Phillips: A bit less frenetic. I mean, there's too much ... traffic and ... all those factors. And too much development of the wrong sort ... which is destroying the character of the island. But there's, there is still a huge expanse of the island which certainly, when you've been away and you come back, you're always damn glad to have come back. The pace of life ... though it's catching up all the time with the mainland ... always lags behind.

Adam Grydehøj: I was told 20 years by two people.

Renella Phillips: Yeah, I don't know if it's quite 20 years now.

Alan Phillips: I don't know if it is - it used to seem like a lot more.

Renella Phillips: It's probably about five now. Yeah. And of course, there's always moves afoot to make us more like the mainland.

Even Pema Brunet (31), warden at the National Trust-managed hamlet of Newtown and a native of Warwickshire who only moved to the island three years previously, speaks approvingly of this "time warp" aspect:

It was more like a snapshot in time from maybe 30 years ago. If you go out trying to organize a wedding, go to the wedding fairs and shops, it doesn't look like mainland sort of stuff to me ... I think, if you go to Ventnor, you can sit at the top of a botanic garden and feel like you're closer to Brazil than to Southampton. That's how I think it's kind of special because it's, like, a little bit exotic, but it's also a little bit backwards as well. 
This attribution of a time warp quality serves as an unanalyzed cliché in descriptions of life on the island and, indeed, in many islands (for instance, Khamis, 2011 referring to Lundy island).

Although the time by which the IOW is said to lag behind the British mainland is usually given as 20 or 30 years, our contributors are not expressing nostalgia for the early 1990s or the early 1980s. Rather, they are harkening back to an earlier age of manorial agriculture as well as the timeless Victoriana of the British seaside holiday culture - i.e., the "staged authenticity" (MacCannell, 1973, 1999) of (supposedly) "quintessential Englishness", performed for tourists and increasingly adopted and internalized by islanders over the past century. It is thus ironic that this "old-fashionedness" is deemed threatened by (rather than supported by) the constant coming and going of visitors and immigrants.

\section{Local Identity}

That many residents view the IOW through the prism of countryside and seaside English tradition points to the difficulty they have in identifying what makes the island distinctive. In fact, there is a feeling that the island is England par excellence. Just as "the island is 20 or 30 years behind the mainland" has become a descriptive cliché, there is also a "the island is England in microcosm" cliché within the dialogue concerning local identity. For example, Alan Phillips states without prompting that "the Isle of Wight encapsulates in a fairly small area the whole of England." Sheila Caws (54), originally from Surrey but living in Cowes for the past 30 years, explains that:

We can do woodland, we can do cliffs, we can do downs. We can ... almost ... do heathland. Can't quite do the Lake District... And yet you can always tell which bit of the island you're in.

This cliché is reinforced in the print media, with Time magazine enthusing that "The Isle of Wight is a microcosm of all that's desirable in a U.K. holiday retreat" (Reddy, 2010). In their IOW visitors' guide, Jackie and Chris Parry similarly set out the island's appeal:

Both scenically and culturally, the Isle of Wight is a miniature replica of the south-east of England. It has a reasonably balanced diversity of town and country landscapes, of brashness and sophistication, of modernity and tradition, enabling it to cope with a broad spectrum of tastes. (Parry \& Parry, 2009: 10)

Many other uses of this cliché in the local and off-island media could be given (for instance, on the websites of the International Island Games Association, Wild on Wight, and Red Funnel). However, the microcosm sentiment is sometimes challenged, such as in the following debate between William and Katherine (pseudonym) (36), who was born in the East Midlands of England but has lived on the island for 21 years. When asked what makes the island special, the reply is: 
Katherine: I think it's the fact that we're an island, and we're surrounded by water, and we're detached from everywhere else. [To William.] Your turn!

William: Yeah ... obviously the fact that it's an island. But I mean, it's what you define by "special." I mean, people say how special it is, but I don't find it - it's like the mainland really, with a big river between it. I don't, you know, I don't think it's any more special than the New Forest or the Southampton area or that sort of thing.

Katherine: I disagree. Because I think it's a microcosm, like, of England as I think - it was Tennyson, wasn't it? - there's lots of different environments and landscapes in the 26 miles within the ... 135 miles area, we've got little snippets of different parts of England.

William: Yeah, but I mean, you go down into Dorset and you take 13 miles from the coast, stretch of 26 miles coast, you get a lot of different environmental [areas].

William, who often holidays in the Hebrides, also notes that the excitement coming from having to cross water to get somewhere is "a standard thing for an island," thereby lessening the extent to which islandness per se can act as a marker of uniqueness. The microcosm cliché is only truly effective in isolation: picking up on one of the previous research areas of their interviewer, some contributors suggested that the IOW possesses greater scenic diversity than Shetland in particular. Familiarity breeds appreciation: not only is every place "special", as William suggests, but recognition of scenic diversity is conditioned by local knowledge. To an outsider, the IOW's scenery may not differ much from many other similarly sized areas of Southeast England, just as, to an insider, even a place like Shetland may feature a wide range of natural and built environments.

\section{A Divided Island}

The most common markers of IOW identity - islandness, the "time warp", and the microcosm idea - are not always viewed as strong markers of identity in other island communities. Although there is a general feeling in many islands that life is slower and more peaceful (Royle, 2001), this is usually set forth as the result of cultural factors (i.e., factors in which the islanders can take pride) rather than as the result of islandness itself (i.e., an accident of nature). Why has the IOW not developed a distinct cultural identity?

Sheila Caws notes that IOW residents identify primarily with their particular regions within the island rather than with the island as a whole:

Where there's a strong sense of community, it is your local community, not the island. Your initial loyalty is to your village. 
Such a sentiment is perhaps unsurprising on an island in which the administrative centre, Newport (population 24,000), does not function as the focal point for life across the island. Other significant towns are ranged around the island, primarily on the north and east coasts: Ryde $(30,000)$, Cowes $(9,500)$, Shanklin $(8,500)$, Sandown $(6,500)$, Ventnor $(6,500)$, East Cowes $(6,000)$, and Freshwater $(5,500)$. The tourism-driven economy ensures that these towns possess cultural and entertainment opportunities disproportionate to their size. As a result, an individual living in Ryde might not have much reason to visit Newport, a resident of Sandown might spend little time in Cowes, and so on.

This situation contrasts with island settlement patterns elsewhere in Northern Europe. Although exceptions exist (such as Skye and the densely populated Channel Islands), most Northern European small islands feature a single centre of population and activity complemented by a number of peripheral settlements: for instance, a third of the Isle of Man's population lives in the town of Douglas, a third of Shetland's population in Lerwick, a third of Bornholm's in Rønne, $40 \%$ of Faroe's in Torshavn, $40 \%$ of Åland's in Mariehamn, $40 \%$ of Gotland's in Visby, $40 \%$ of Orkney's in Kirkwall, and $60 \%$ of Iceland's in Reykjavik. Ryde, however, possesses just above $20 \%$ of the IOW's population. Indeed, many contributors from the "Back of Wight" - for which Newport is the definite centre of shopping and cultural activities - mistakenly believe that Newport is the island's largest settlement. In addition, proximity to large mainland towns means that some residents effectively import much of their cultural and economic lives.

The IOW's industrial diversity also obstructs the development of a unitary island identity. Ryde, Shanklin, and Sandown are characterized by various forms of family-oriented seaside tourism, tinged with identification with the historical small-scale fishery; Cowes is greatly influenced by its yachting culture; East Cowes still bears the influence of its historical largescale shipbuilding industry; and the countryside character of the "Back of Wight" and much of the interior of the island means that an agricultural rather than a maritime identity predominates. Furthermore, ever since the opening of Parkhurst prison in 1835 (followed by Camp Hill prison in 1912 and Albany prison in 1967), prison services have played a significant role in the island's economy. Economically beneficial as prison service jobs may be, the prison services industry is peculiarly ill suited to identity building. 
Figure 3: Chain ferry connecting the distinct communities of Cowes and East Cowes, Isle of Wight.

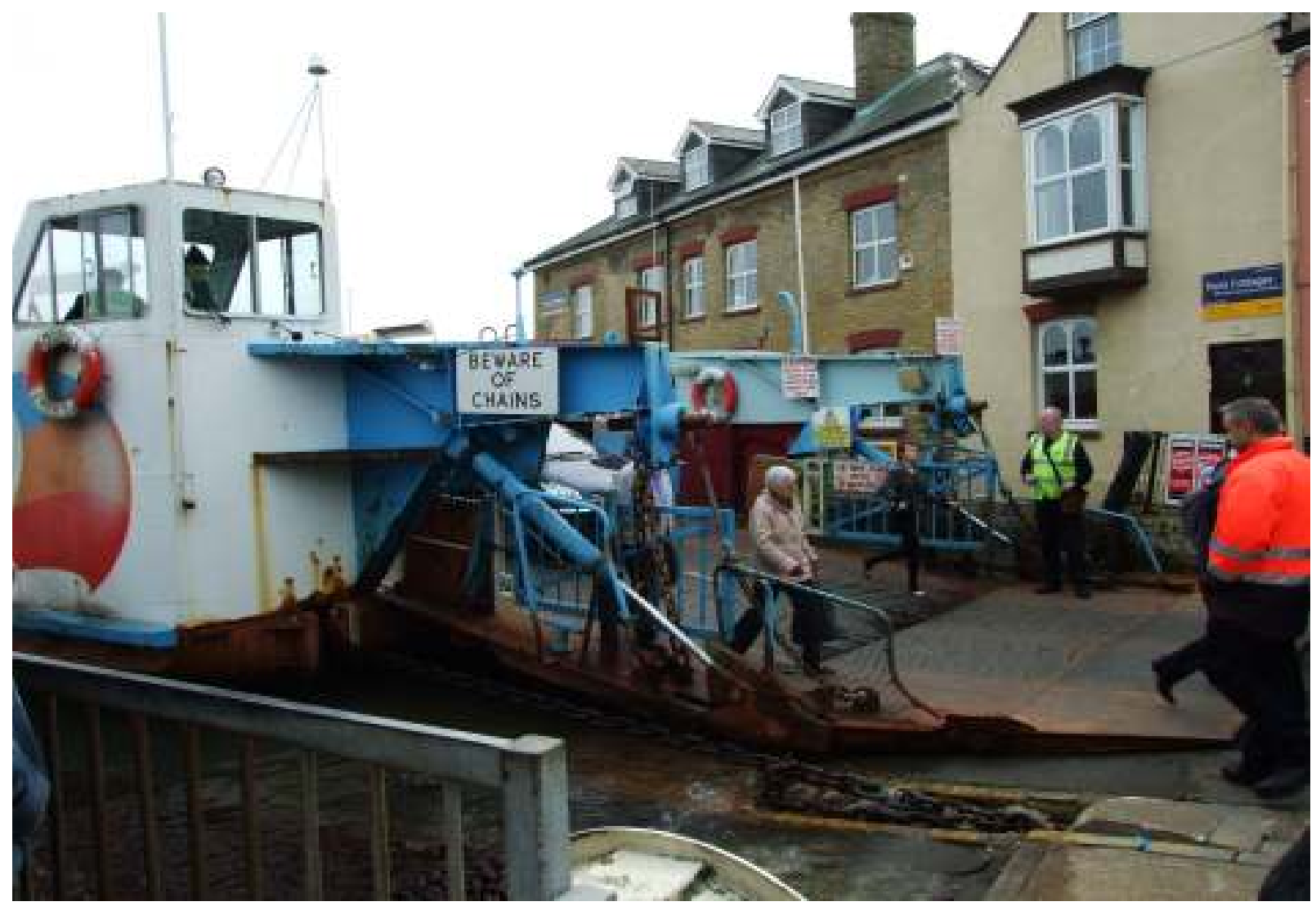

Photo by Adam Grydehøj

\section{Generic Identity and the Failure of Autonomist Politics}

When explaining the island's uniqueness, Katherine refers to Alfred, Lord Tennyson. Indeed, this Victorian poet, who relocated to the island in 1852, is often an unstated referent in discussions of IOW identity. Tennyson's death was commemorated with a granite stone cross erected on the island in 1897 along what is now promoted as a section of the "Tennyson Heritage Coast" of Southern England. Tennyson's perceptions of the island were conveyed in an 1854 untitled poem written to the Reverend F.D. Maurice, inviting him to "come to the Isle of Wight":

Where, far from the noise and smoke of town

I watch the twilight falling brown

All around a careless-ordered garden

Close to the ridge of a noble down. 
You'll have no scandal while you dine

But honest talk and wholesome wine

And only hear the magpie gossip

Garrulous under a roof of pine.

Similar to Tennyson's verse, the $21^{\text {st }}$ Century incarnation of the VNP bases its vision of contemporary and autonomist IOW identity on the idea of the island as a quaint relic of bygone English romantic rurality and a refuge from metropolitan life. This recalls Baldacchino's assertion that the "cultural and historical landscape of an island can be manufactured in much the same way that a community can be 'imagined' into existence via political intent" (2004: 272).

While the new VNP makes frequent reference to Channel Island and Manx autonomy, a more fruitful comparison might be with the local political initiatives that took place from the mid1960s onwards in outlying British communities not already possessing substantial autonomy. An example is the Mebyon Kernow ("Sons of Cornwall") movement and political party, which was founded in 1951 to foster Cornish self-rule (see Deacon, 2003) in this tourism-dependent community. Despite Mebyon Kernow's similar failure to gain a substantial share of votes in national elections, its sustained support base continues to elect Mebyon Kernow representatives onto local and regional councils. This political presence has contributed to the securing of recognition of and assistance for many Cornish social, political, and cultural initiatives.

The key difference between the parties established to promote autonomy is cultural. Although the new VNP sees autonomy as a means of fostering "the island's unique culture" (VNP, 2006), the party makes little reference to any aspect of island culture apart from those of quaintness, rurality, and slow pace. This is a significant limitation in the "imaginative" cultural underpinning of the initiative. By contrast, Mebyon Kernow could access a powerful "proof" of cultural difference from England in the form of the (revived) Cornish language and a history of unarguably distinctive Cornish song and drama. Indeed, two of the organization's seven founding aims were specifically cultural: "to foster the Cornish Language and Literature" and to "arrange concerts and entertainments with a Cornish-Celtic flavour through which [our] aims can be further advanced" (Mebyon Kernow, 2007 [1951]).

The Celtic nature of the Cornish language offered a further advantage. Welsh and Scottish Gaelic language cultures were powerful elements in the rhetorical bases of the Welsh nationalist party Plaid Cymru (first national electoral success in 1966) and the Scottish National Party (first national electoral success in 1967; majority in the Scottish Assembly after the 2011 election) respectively. Similar harnessing of linguistic difference for autonomist ends can be seen, for example, with the Shetland dialect in Shetland, Jèrriais in Jersey, Guernésiais in Guernsey, Faroese in Faroe, Swedish in Åland, and Corsu in Corsica. With neither distinctive language and culture, nor widespread discontent over English historical hegemony, the VNP and other expressions of IOW autonomist sentiment possess an essentially "soft" cultural core. This cultural core is innately bound to notions of idyllic English ruralism suitable for and reflective of English middle-class sensibilities. 
And yet, this conception of island identity competes against other narratives even within the local tourism industry itself. The Isle of Wight Festival helps underline the fact that a heritagecentred vision of IOW identity is untenable on a general level. This annual popular music festival began in 1968, but it was the 1970 festival that established an image in the British media of the IOW as home to "Britain's Woodstock". This festival attracted around 600,000 attendees who watched five days of performances by major international acts such as Jimi Hendrix, the Who, the Doors, Chicago, and Emerson, Lake, and Palmer. Following a 32-year hiatus, the Isle of Wight Festival was revived in 2002, and although it has never reached the visitor numbers of the earlier festivals, the Isle of Wight Festival remains the best-known IOW cultural event among both island residents and visitors. The Isle of Wight Scooter Rally is another annual event with which the island is associated but which meshes poorly with the general conception of local heritage. Even if tourist-oriented heritage could be claimed for the purpose of building local identity, the existence of competing tourism narratives - whether regarding yachting, motorsports, or rock ' $n$ ' roll - make it difficult for the community as a whole to sculpt this into a unified yet distinctive quasi-national narrative.

\section{Conclusion}

The IOW conforms to Baldacchino's (2004) observation that islandness does not necessarily engender separatist impulses. More particularly, our analysis identifies the manner in which the IOW lacks the first "necessary condition" for ethnopolitical mobilization behind autonomy identified by Cartrite in his analysis of the extent of ethnopolitical mobilization in Faroe, Shetland, and Orkney, i.e., that "cultural traits shared by a (sub)set of individuals must be understood by them as in fact delineating a group distinct from other groups" (2010: 242).

Aside from the activities of the VNP, the IOW has been strikingly free from autonomist and devolutionist sentiment. This can be explained by the island's lack of a unitary identity, romantic historical narrative, and sense of cultural heritage. These aspects can, in turn, be explained by long-term high levels of immigration, the existence of numerous centres of population, and a diversity of unevenly distributed industries. Whereas many island communities respond to an influx of tourists and immigration by gathering around a shared identity concept that is oppositional in nature, this has not occurred on the IOW. Indeed, the presentation of the IOW as a microcosm of England is the antithesis of an oppositional identity: although residents tend to feel that the IOW is superior to the mainland, this exceptionalism is not rooted in the local identity concept, which places the island firmly within England. Thus, whereas Shetlanders distinguish themselves from the Scots, Channel Islanders from the English and French, the Faroese from the Danes, Allanders from the Finns, Corsicans from the French, and so on, there is no oppositional 'other' to demarcate an IOW identity.

A lack of feeling of cultural distinctiveness precludes in practice the pursuit of political distinctiveness. That there nevertheless exists anti-immigrant sentiment and concerns about importing the "bad habits" of the mainland is thus somewhat worrisome: the IOW possesses some negative characteristics of nationalism (such as resistance to outside ideas, and barriers to immigrants integrating into the community of natives) without accruing the positives (such as a strong sense of community ownership and engagement in local policymaking and cultural initiatives). 
In 2009, following a local design competition, a new IOW flag was accepted by the British Flag Institute (the national registry of UK flags) to replace the old, more traditionally heraldic flag of the IOW Council (a design comprised of Carisbrook Castle and three anchors). The new flag offers a distinctly modernist image of a horizontally elongated diamond with a cleft in the top centre (representing the island) floating above a wave design (see Figure 4). But this exercise in re-branding neither reflects nor affects any significant modernization of an island identity - or "product" - that is premised on stability and a sense of historical nostalgia. The IOW's position in the early 2000s is essentially a stable one, attracting mainland tourists and retirees to a number of carefully nurtured heritage regions - a vision notably satirized in Julian Barnes's 2005 novel England, England in which an obsessive entrepreneur turns the whole island into a theme park simulacrum of lost, quintessential Englishness. It is thus no surprise that greater autonomy lacks a place on the IOW political agenda.

Figure 4: The new Isle of Wight flag (Downloadable from: http://en.wikipedia.org/wiki/File:Flag_of the Isle_of_Wight.svg)

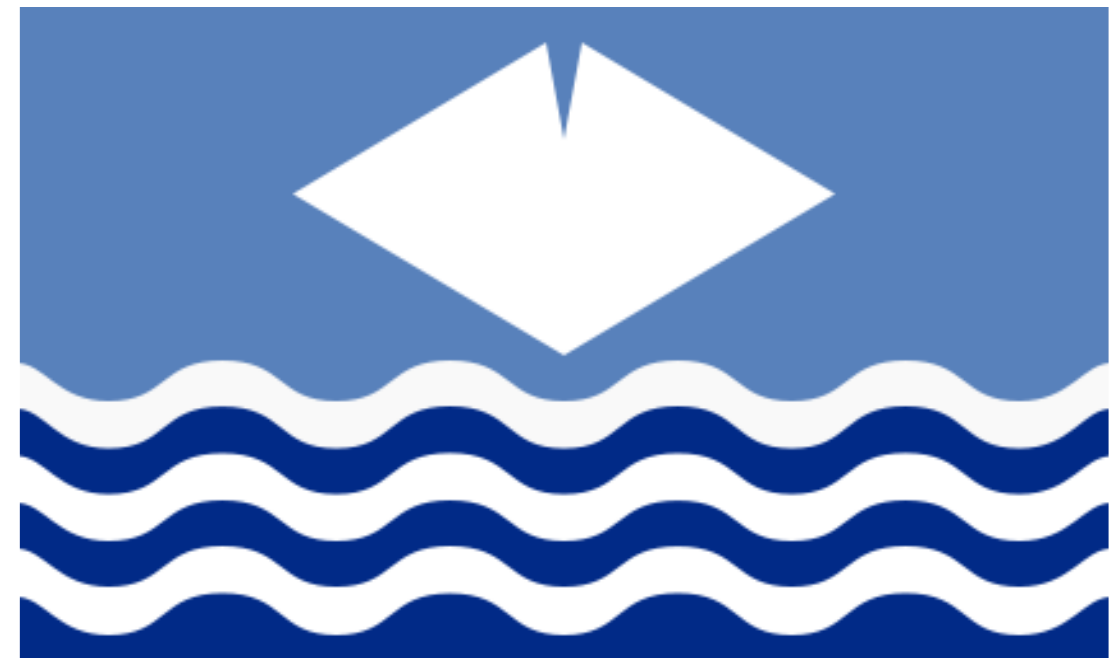

\section{Acknowledgements}

Special thanks is due to Alan Phillips, whose facilitations of IOW fieldwork and extensive local knowledge helped make this article possible, and to the ISJ referees who provided valuable feedback on earlier versions of this article. 


\section{References}

Anderson, B. (1983) Imagined Communities: Reflections on the Origins and Spread of Nationalism, London, Verso.

Baldacchino, G. (2004) 'The Coming of Age of Island Studies', Tijdschrift voor Economische en Sociale Geografie, Vol. 95, No. 3, pp. 272-282.

Baldacchino, G. (ed.) (2007) Bridging Islands: The Impact of Fixed Links, Charlottetown, Canada, Acorn Press.

Baldacchino, G. (2010) Island Enclaves: Offshoring, Creative Governance and Subnational Island Jurisdictions, Montreal QC, McGill-Queen's University Press.

Baldacchino, G. \& Royle, S.A. (eds.) (2010) 'Postcolonialism and Islands', special issue, Space and Culture, Vol. 13, No. 2.

Barnes, J. (2005) England, England, London, Picador.

Bartmann, B. (2000) 'Patterns of Localism in a Changing Global System' in G. Baldacchino and D. Milne (eds.) Lessons from the Political Economy of Small Islands: The Resourcefulness of Jurisdiction, New York, St. Martin's Press, pp. 38-55.

Brasher, S. (2011) 'The Returning Officer: Regionalists', New Statesman, 14 February.

Cartrite, B. (2004) 'Complexity and Ethnopolitical Mobilization', presentation to IPSA Research Committee Politics \& Ethnicity, www.sas.upenn.edu/ cartrite/research/ComplexityAndEP.pdf.

Cartrite, B. (2010) 'Ethnopolitical Mobilization in the North Sea Region', Nationalism and Ethnic Politics, No 16, pp. 240-261.

Deacon, B. (2003) Mebyon Kernow and Cornish Nationalism: The Concise History, Cardiff, Welsh Academic Press.

Dennis, T. (2002) 'The Principality of Sealand: Nation Building by Individuals', Tulsa Journal of Comparative \& International Law, Vol. 10, No. 1, pp. 261-292.

European Commission (1999) 'Council Regulation (EC) No 1260/99 of 21 June 1999 laying down general provisions on the Structural Funds', http://europa.eu/legislation_summaries/regional_policy/provisions_and instruments/160014_e n.htm.

Grydehøj, A. (2011) “'It’s a Funny Thing that they were all Bad Men”: Cultural Conflict and Integrated Tourism Policy', International Journal of Tourism Anthropology, Vol. 1, No. 2, pp. 125-140. 
Grydehøj, A. (2010), 'Uninherited Heritage: Community Reaction to Heritage without Inheritors in Shetland, Åland, and Svalbard', International Journal of Heritage Studies, Vol. 16, No. $1-2$, pp. $77-89$.

Hjalager, A.M. (1998) 'Environmental Regulation of Tourism: Impact on Business Innovation', Progress in Tourism and Hospitality Research, Vol. 4, No. 1, pp. 17-30.

International Island Games Association (n.d.)

www.islandgames.net/cms/member_profile_12368.html.

Isle of Wight Community Council (2009) 'Listening to Minority Ethnic Communities on the Isle of Wight', discussion document, www.equalsiw.org.uk/bp_local/.../20091002_rcc_forum_report.pdf

Isle of Wight Council (2005) 'Island Plan Core Strategy Sustainability Appraisal and Strategic Environmental Assessment Scoping Report'.

Isle of Wight Party (IWP) (2001) 'Isle of Wight Party (IWP) Manifesto', www.invectis.co.uk/iow/iwpp.htm.

Johns, A. (2010) Death of a Pirate: British Radio and the Making of the Information Age, London, Norton.

Khamis, S. (2011) 'Lundy's "Hard Work": Branding, Biodiversity and "A Unique Island Experience", Shima: The International Journal of Research into Island Cultures, Vol. 1, No. 1 , pp. 1-23.

Long, W.H. (1886) A Dictionary of the Isle of Wight Dialect and of Provincialisms used in the Island, London, Reeves \& Turner, www.round-theisland.co.uk/isle_of_wight_dialect/dialect.htm.

MacCannell, D. (1973) "Staged Authenticity: Arrangements of Social Space in Tourist Settings', American Journal of Sociology, Vol. 79 No.3, pp. 589-603.

MacCannell, D (1999) The Tourist: A New Theory of the Leisure Class, Berkeley CA: University of California Press.

Mebyon Kernow (2007 [1951]) 'The History of Mebyon Kernow', www.mebyonkernow.org/?q=history the history_of mk.

Odedra, L. (2010) Isle of Wight Residents' Survey - January 2010, Birmingham, BMG Research.

Office for National Statistics (2011) Focus on Ethnicity and Identity, London, HMSO. 
Parry, J. \& Parry, C. (2009) Isle of Wight, London, Landmark Publishing.

Reddy, J. (2010) 'Five Reasons to Visit the Isle of Wight', Time, 16 September, www.time.com/time/travel/article/0,31542,2019553,00.html\#ixzz104XdZiaE.

Red Funnel (n.d.) www.redfunnel.co.uk/island-guide.

Rogers, S. (2011) 'Ethnic breakdown of England and Wales mapped' (interactive map), The Guardian (UK) Online, 19 May, www.guardian.co.uk/news/datablog/interactive/2011/may/19/ethnic-breakdown-englandwales.

Royle, S.A. (2001) A Geography of Islands: Small Island Insularity, London, Routledge.

Shakespeare, W. (1605) Macbeth, www.gutenberg.org/ebooks/2264.

Streeten, P. (1993) 'The Special Problems of Small Countries', World Development, Vol. 21, No. 21, pp. 197-202.

Tetteh, E. (2008) Election Statistics: UK 1918-2007, Research Paper 08/12, Social \& General Statistics Section, House of Commons Library.

United Nations (1960) 'Declaration on the Granting of Independence to Colonial Countries and Peoples', www.un.org/Depts/dpi/decolonization/declaration.htm.

Vectis National Party (VNP) (2006) http://vectisparty.fortunecity.com.

Wild on Wight (n.d.) www.wildonwight.co.uk.

\section{Discography}

Lauri Say and the Island Folk (1968) Songs for Singing Islanders, Saydisc, Catalogue No. 33SD 140. 